\title{
Technological gap in allspice (Pimenta dioica L. Merr) production
}

\author{
Santos-Vazquez, Cristian ${ }^{1 *}$; Valdivia-Alcalá, Ramón ${ }^{1}$; Reyna-Izaguirre, Diana América ${ }^{1}$; \\ Márquez-Berber, Sergio, Roberto ${ }^{1}$; Montalvo-Hernández, Domingo ${ }^{1}$
}

${ }^{1}$ Universidad Autónoma Chapingo.

*Corresponding author: csantosvzq@outlook.com

\begin{abstract}
Objective: To study the technological features of allspice (Pimenta dioica L. Merr) production and to show potential areas of social intervention in the crop.

Methodology: The study took place in five of 22 producing municipalities in Veracruz state, Mexico, selected by nonprobabilistic sampling; $n=50$ surveys were applied to producers selected following the snowball method. Data were collected on profile of the production unit and knowledge-practice for innovations. Descriptive statistics were applied: knowledge-practice rates and knowledge-practice indices were calculated. A classification of areas of opportunity was made based on the diffusion of innovations theory.

Results: Allspice occupies small areas, its a complementary crop; knowledge and practice rates show that the categories for marketing, organization and nutrition are the lowest; in the opposite direction are the categories for harvesting. sustainable management and agronomic management. The categories show areas of opportunity for intervention, for the less known and practiced innovations; as well as opportunity for reinvention of known and practiced categories. Study limitations: Due to difficult access to producer databases, it was decided to conduct a snowball sampling method. Conclusions: The increase in knowledge and practice rates are determined by the areas of opportunity and the restructuring of the known innovations. The role played by allspice, the occupied surface and the presence of other commercial crops can explain the state of production.
\end{abstract}

Key words: Innovation, Knowledge index, Practice index, Production.

\section{INTRODUCTION}

Spices have accompanied the development of mankind since ancient times; these were reason for SPICeS conquests and expansion to new territories (Claridades Agropecuarias, 2001; Morales, 2008; Rao et al., 2012). Records suggest that there are 26 thousand species of edible plants with different applications, including all peppers (Morales, 2008). The allspice (Pimenta dioica L. Merr) (Myrtaceae) is a spice native to Mesoamerica, adapted and cultivated in various areas of the world (CONABIO, 1947; Gómez, 2007; Jaramillo, 2014; Reyes-Martínez, 2017).

\section{Agroproductividad: Vol. 14, Núm. 5, mayo. 2021. pp: 93-99.} Recibido: octubre, 2020. Aceptado: mayo, 2021. 
Several studies record that allspice has been used in the food industry, cosmetics and perfumery (Macia Barco, 1998; Monroy Rivera, 2011; Rao et al., 2012). Other research report that different active ingredients extracted from allspice present anticancer, antifungal, antimicrobial, nematicide, antioxidant, antidiabetic and anti-inflammatory activity, which is used by the pharmaceutical industry (Lim, 2012; Rema \& Krishnamoordthy, 2012; Sol-Sánchez et al., 2018; Zhang \& L. Lokeshwar, 2012).

In Mexico, in order of importance, allspice production is concentrated in the states of Veracruz, Tabasco, Chiapas and Puebla (Jaramillo, 2014; Martínez-Pérez et al., 2013). According to Gómez (2007); Jaramillo (2014) and Martínez-Pérez et al. (2013) most of this production comes from plots where allspice is grown as a complement to a main activity, with little agronomic management and dispersed in pastures.

Martínez-Pérez et al. (2013) reported that through innovation management agencies, the adoption of the allspice technological package was promoted as part of the Humid Tropics Program, resulting in a low integration of new forms of production and organization by producers, especially in the state of Veracruz. In the same way, little interest has been documented on the producers to carry out agronomic practices on this crop (Martínez-Pérez et al. 2013; Reyes-Martínez, 2017).

An accelerated adoption of innovations, according to Ullah et al. (2020), results in a positive growth in agricultural productivity, sustainable agricultural land use and an overall path to food security. To expand practice in agriculture, Zainal and Hamzah (2018) stated that the improvement of farmers' knowledge is required; also, Odame et al. (2020) stated that, knowledge specific to each area and that provided by science should be integrated; in this way a holistic approach to the practices proposed to farmers can be achieved. Based on the above, the technological aspects in the production of allspice were studied to show potential areas of social intervention for this crop.

\section{MATERIALS AND METHODS}

The research took place in five of 22 allspice-producing municipalities at Veracruz, Mexico (Altotonga, Atzalan, Catemaco, Misantla and Tlapacoyan). These were selected by non-probabilistic sampling directed to convenience based on the production records by municipality of the SIAP (2018). During June and July 2019, $n=50$ producers of allspice sampled by the snowball method were interviewed.

A survey of 24 questions and a catalog of 28 innovation practices were designed, divided into the categories for: nutrition, plant health, sustainable resource management and establishment of the plantation, administration, marketing, organization, harvest and postharvest; and agronomic management; which was adapted from the UTE-Innovation proposal (2013). In the survey, data was collected on the profile of the production unit, as well as the knowledge and implementation of innovation practices in its production units (Table 1).

The information collected from the surveys was captured in a mask designed for that purpose; the data of the producer's profile and the production unit were processed to obtain descriptive statistics. The information from the innovation practices catalog was captured and coded to obtain: the knowledge rates and practice rates by category; as well as the knowledge index and the innovation practice index.

The knowledge index (KIn) and the practice index (PIn) were constructed following the methodology proposed by Muñoz-Rodríguez et al. (2007) of the innovation adoption index IAln. The Kln and Pln consist of mapping what the producers knows and what they know and does.

The way to compare between the indices for its interpretation is to make it similar to the IAln in the following way: the baseline is pared to the knowledge index and the final line is pared of the practice index. The difference between the baseline and the final line gives the gap of the increase or decrease in time, in the case of the difference between Kln and Pln we obtain the gap of what is known is being applied. While the timeline that clearly distinguishes IAln is not examined, the existing gap between Kln and Pln can help to clarify what actions to take in addressing areas of opportunity for allspice production.

The areas of opportunity were determined as a basis in the theory of innovations diffusion proposed by Rogers (1995), where five categories to classify the units that adopt innovations were defined. The first two categories (Innovators [2.5\%], early adopters [13.5\%]) were taken as the areas with the greatest opportunity for intervention, 
Table 1. Innovations catalogue.

A1. Analysis for the determination of fertilization dose

A. Nutrition

A2. Soil amendment techniques: lime, sulfur, manure

A3. Macroelements: Nitrogen, phosphorus, potassium, calcium, magnesium and sulfu

A4. Microelements: Zinc, manganese, boron, iron and copper

B5. Pest and disease monitoring

B. Plant Health

B6. Sanitary pruning

B7. Formation pruning

B8. Control of pests and diseases

C9. Organic fertilizers, compost and vermicompost

C. Sustainable resource management and plantation establishment

C10. Crops with which allspice can be associated

C11. Plantation establishment specifications based on specific requirements or technological package for allspice (density, agroclimatic, edaphological, etc.)

D12. Scheduling of activities / processes

D. Administration

D13. Register the practices carried out in the cultivation (date, inputs, practice)

D14. Register the quantity and quality of the harvested fruit

E15. Register the income and expenses of the production unit

E. Commercialization

E16. Consolidated purchases

E17. Consolidated sales

F18. Advisory services, financial services

F. Organization

F19. Plantation management activities

F20. Allspice Producers Organization

G21. Scheduling for the collection and sale of allspice

G22. Tools that facilitate harvesting (tall limb pruner, scissors, chain saws)

G. Harvest and postharvest

G23. Sale of fresh allspice

G24. Sun drying process

G25. Drying process with machines

H26. Plants of varieties improved or validated varieties in the production unit

H. Agronomic management

H27. Own plants with better yields and resistance to diseases

H28. Grafted allspice plants

Source: Adapted in 2019, based on the approach UTE-Innovación (2013).

the third category (earlyest [34\%]) as those requiring reinforcement, and finally the fourth and fifth categories (latest [34\%] and laggards [16\%]) where interventions are no longer necessary and possibly present an area of opportunity to rethink these innovations.

\section{RESULTS AND DISCUSSION}

The general profile of allspice production shows that their production units mainly cultivate bananas, coffee, corn, lemon, and other crops. In some cases, cattle are raised; allspice occupies a role different from the main crop in $96 \%$ of the cases. The results show that for producers who have diversified production systems, with more than two crops, allspice occupies an average of $39 \%$ of the surface, and for producers who have diversified production systems with just two crops, allspice represents on average $71 \%$ of the area sown.

The mapping of the innovation catalog showed the level of knowledge and practice by category; the lowest knowledge rates were marketing (19\%), organization $(19 \%)$ and administration (37\%); with the exception of the administration category, these categories also had low practice rates, $6 \%$ and $5 \%$ respectively, adding to this list the nutrition category (10\%). The categories with the highest knowledge rates were harvest (77\%), sustainable management and plantation establishment 


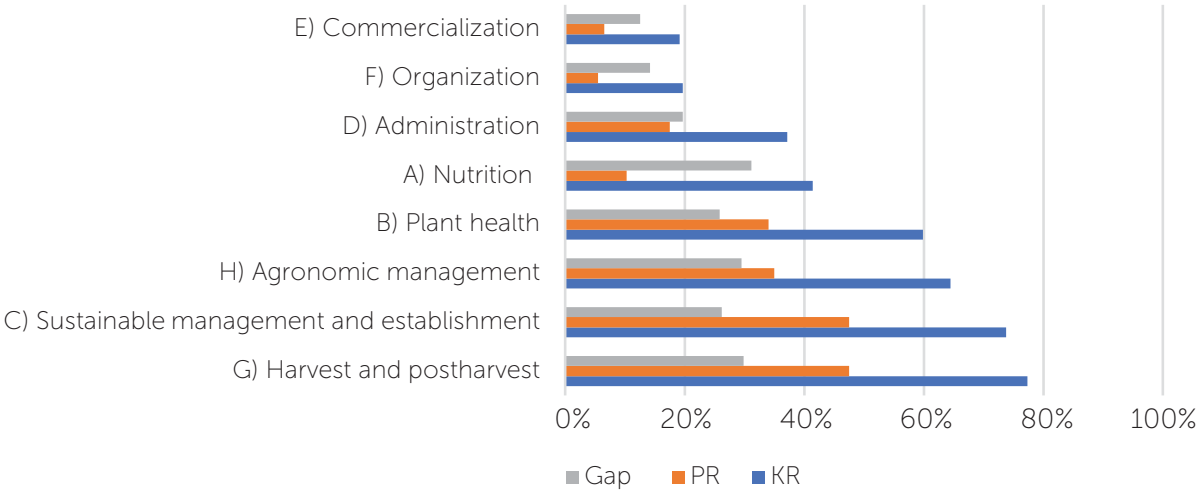

Figure 1. Knowledge (KR) and practice (PR) rates by category (2020). the recording of practices carried out on the crops, as well as the recording of the quality and quantity of the harvested fruits.

The best-known innovations present the largest gaps; in category A) for nutrition these are: soil amendment techniques and the application of microelements; in category $\mathrm{H}$ ) agronomic management, these were the selection of plants with better yields and resistance, as well as the usage of grafted plants; the last in this classification is category G) harvesting, where the least practiced innovations were the sun-drying process and machines drying.

\section{Areas of opportunity}

Important areas of intervention are found in innovations the A1, analysis for determining fertilization doses, A4 microelements, D14 recording the quantity and quality of harvested fruit, E16 consolidated purchases, E17 consolidated sales, F18 advisory services and financial services, F19 group management of the plantations, and F20, organization of allspice producers. Given that
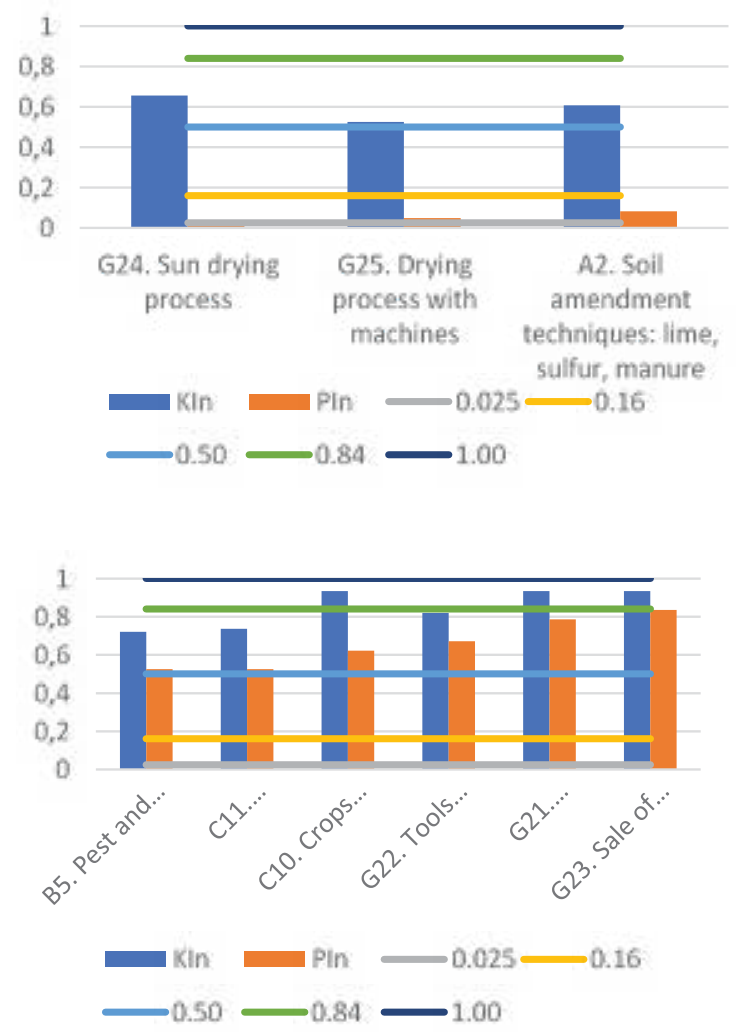

Figure 2. Knowledge Index (KIn) and Practice Index (PIn) by Opportunity Areas (2020)
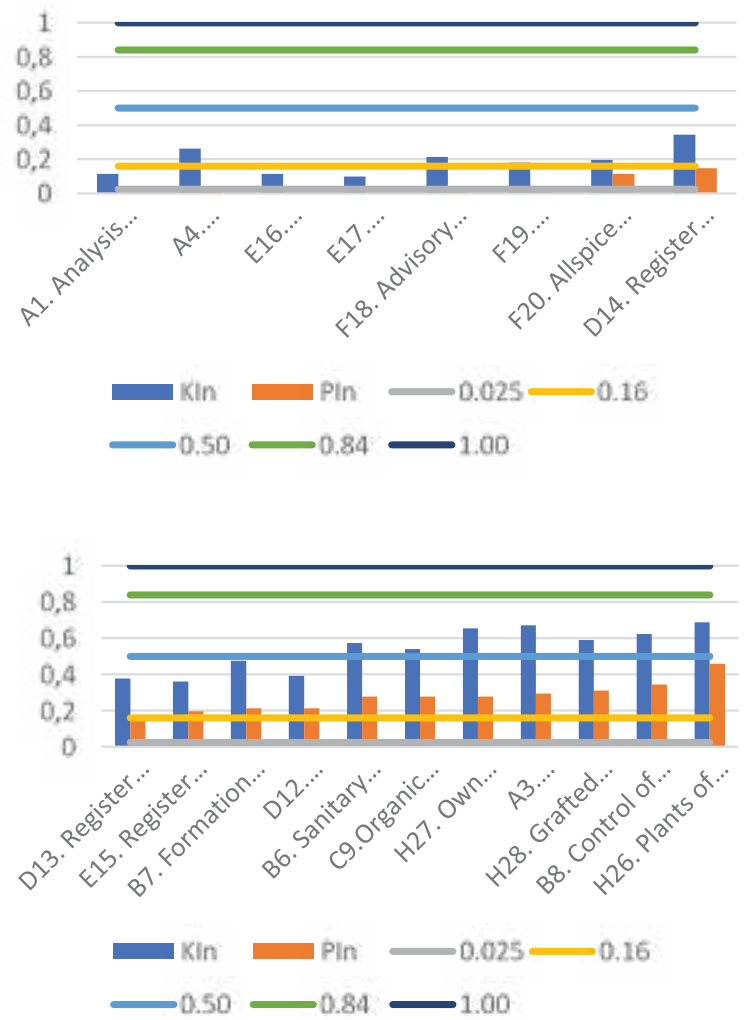
these are the least known and practiced, they provide an opportunity to insert this knowledge into the producers' production systems.

The innovations that presented a lower than 0.50 index in the practice were: A3 macroelements, B6 sanitary pruning, B7 formation pruning, B8 pest and disease control, C9 application of organic fertilizers, compost and vermicompost, D12 calendarization of their activities/processes, D13 recording of the practices carried out in the crops, E15 recording of income and the expenditure of the production units, H26 improved or validated varieties in the production unit, H27 own plants with better yields and diseases resistance and H28 grafted allspice plants; these innovations already flow among the activities of the producers; however, they are not yet fully present, so they may be reinforced through interventions or training. Although in some cases, these innovations exceed 50 \% of knowledge, there is still a gap with the PIn, which can be addressed with interventions.

Wide technological gaps were found in some mapped innovations, which require further study to understand the situation that leads to their existence. Such activities were related to A2 soil amendment techniques: lime, sulfur, manure, G24 sun drying process and G25 machine drying process.

In the activities where the knowledge and practice index is higher than 0.50, promotion is not necessary, because at that presence level, the innovations can no longer be influenced; therefore, the practice must reach the producers. These innovations are B5 monitoring of pests and diseases, C10 combination of allspice with other crops, C11 specifications for plantation establishment, G21 harvest and selling of allspice programming, G22 tools for harvesting facilitation, G23 sale of fresh allspice. This represents an area of opportunity to rethink these activities, towards the generation of innovations that create value for the producers; and therefore the improvement of the current forms of production.

The results show that in the presence of other crops, allspice occupies smaller surfaces; in production systems with more than two crops, it occupies even less area; in systems where there are two crops, allspice occupies a larger area. This difference could be explained by the economic contribution of the crops and the role played by each of those that make up the production system.

The above concurs with that reported by Ayala-Garay et al. (2016) who found that the interaction of surfaces and the presence of profitable crops can displace those that are not and such a condition may be determined by the emplaced agronomic practices.

The analysis found that the categories: marketing, organization and administration have the lowest rates of knowledge and practice. Within these, it was possible to detect that consolidated purchases and sales are not taking place, the hiring of advisory services, the management of the plantation, and the recording of the quality and quantity of the product. Previous studies in other crops showed that the organization is the category with the least adoption by producers (Andrade-Saavedra et al., 2019; Vargas-Canales et al., 2018).

The three least practiced categories correlate, since consolidated sales cannot be generated against intermediaries if there is no organization, nor can prices be negotiated if there are no quality records. These puts allspice producers at a disadvantage in obtaining resources for their development. Regard the above, there are studies that affirm that disorganization leads producers to a fragile profitability and little negotiating power (Ayala-Garay et al., 2014; García-Sánchez et al., 2018; Jaramillo, 2014).

The results show that the greatest gap categories are: harvest, sustainable management and plantation establishment, agronomic management and nutrition. In contrast, González-Cruz (2019) reported that, in the case of allspice producers at the state of Puebla, Mexico, the least adopted category corresponds to nutrition; and categories such as sustainable harvesting and management are among the most emplaced. It was found that, in the harvest category, the innovation in the sun drying process has one of the largest gaps. Unlike these results, González-Cruz (2019) reports that producers at the state of Puebla are beginning to carry out sun-drying methods.

In order to insert the existing knowledge in the practices for allspice production, activities with lower knowledge levels and practices can be promoted; This contribute to the improvement of the productive state of the crop. There is evidence from Ayala-Garay et al. (2016) 
and Muñoz-Rodríguez et al. (2007), that the adoption of innovations moves in tune with the increase in productivity.

Finally, the innovations that are in a higher than 0.5 position, are the area of opportunity to rethinking these activities towards innovations that offer advantages. As proposed by Rogers (1995), innovation must present: relative advantage, compatibility and complexity, both experimental and observable.

\section{CONCLUSIONS}

The secondary role played by allspice regard the amount of surface occupied in the plots and the presence of other commercial crops already developed may be the explanation of why allspice have remained in its current productive state. There are producers who are already entering a better-established cultivation system and management, different from conventional; these are the producers that present an index of knowledge of innovations with opportunity areas; In the same sense, these are the producers who also present the indexes of practice of the innovations different from those already carried out by most of the producers.

By understanding the technological aspects in the production process of allspice, the areas that need to be rethought are evident, as well as which ones need to be promoted; with the proposed mapping, it is possible to identify the activities that already flow into what to do for the producers, as well as those that are not yet fully circulating among their knowledge and practices.

The existing gap of practical knowledge can be an area of opportunity for intervention, so that these indices increase, the differentiation of the indices in proposed groups can be the first way to this end.

\section{REFERENCES}

Andrade-Saavedra, Z. X., Ocampo-Ledesma, J. G., Aguilar-Ávila, J., \& Palacios-Rangel, M. I. (2019). Resiliencia en empresas de agricultura protegida. La situación en Yecapixtla, Morelos, México. [Universidad Autónoma Chapingo]. http://repositorio. unan.edu.ni/2986/1/5624.pdf

Ayala-Garay, A., Espitia-Rangel, E., Rivas-Valencia, P., Almaguer-Vargas, G., \& Preciado-Rangel, P. (2014). Análisis del sistema productivo de amaranto en Temoac, Morelos, México. Ciencia Ergo Sum, 23(1), 49-57.

Ayala-Garay, A., Espitia-Rangel, E., Rivas-Valencia, P., Martínez-Trejo, G., \& Almaguer-Vargas, G. (2016). Análisis de la cadena del valor de amaranto en México. Agricultura Sociedad y Desarrollo, 13(1), 87. https://doi.org/10.22231/asyd.v13i1.280

Claridades Agropecuarias. (2001). La pimienta una especia milenaria, en un mercado especial. InfoAserca, 96, 28. http://www. infoaserca.gob.mx/claridades/revistas/096/ca096.pdf

CONABIO. (1947). Pimenta dioica. Contributions from the Gray Herbarium of Harvard University, 37(1), 198-200. https://doi. org/10.1021/np0705615

García-Sánchez, E. I., Vargas-Canales, J. M., Palacios-Rangel, M. I., \& Aguilar-Ávila, J. (2018). Sistema de innovación como marco analítico de la agricultura protegida en la region centro de México. Cuadernos de Desarrollo Rural, 15(81), 1-24. https:// doi.org/https://doi.org/10.11144/Javeriana.cdr15-81.sima

Gómez, J. R. (2007). Propagación de la pimienta de Jamaica (Pimenta dioica) por estacas terminales con hojas.

González-Cruz, M. (2019). Estrategia comercial para pequeños productores de pimienta gorda de la sierra norte de Puebla. Universidad Autónoma Chapingo.

Jaramillo, V. J. L. (2014). Evaluación y determinación de la escala mínima rentable, de unidades productivas para emprendedores en el campo poblano (1st ed.). Colegio de postgraduados.

Lim, T. K. (2012). Edible Medicinal and Non Medicinal Plants. In Fruits (Vol. 3). https://doi.org/10.1007/978-94-007-2534-8

Macia Barco, J. M. (1998). La pimienta de Jamaica (Pimenta dioica (L.) Merrill, Myrtaceae) en la sierra norte de Puebla (México). Anales Jardin Botanico de Madrid, 56(2), 337-349.

Martínez-Pérez, D., Hernández-García, M. A., \& Martínez-González, E. G. (2013). La pimienta gorda en México (Pimienta dioica L. Merril): avances y retos en gestión de la innovación (1st ed.). Universidad Autónoma Chapingo (UACh), Centro de investigaciones económicas, sociales y tecnológicas de la agroindustria y la agricultura mundial (CIESTAAM). https://doi. org/10.13140/RG.2.1.3644.2080

Monroy Rivera, C. R. (2011). Paquete Tecnológico Pimienta Gorda (Pimenta dioica L. Merril) Establecimiento y mantenimiento (1st ed., Vol. 1). INIFAP.

Morales, M. (2008). Hierbas y especias más utilizadas en México. 39(5), 561-563

Muñoz-Rodríguez, M., Aguilar-Ávila, J., Rendón-Medel, R., \& Altamirano-Cárdenas, J. R. (2007). Análisis de la dinámica de innovación en cadenas agroalimentarias. In Materiales de formación para las agencias de gestión de la innovación (Primera ed, Vol. 53, Issue 9). Universidad Autónoma Chapingo (UACh), Centro de investigaciones económicas, sociales y tecnológicas de la agroindustria y la agricultura mundial (CIESTAAM). https://doi.org/10.1017/ CBO9781107415324.004

Muñoz-Rodríguez, M., Altamirano-Cárdenas, J. R., Aguilar-Ávila, J., Rendón-Medel, R., García-Muñiz, J. G., \& Espejel-García, A. (2007). Innovación: motor de la competitividad agroalimentaria. Políticas y estrategias para que en México ocurra. CIEESTAAM/ PIAI. Universidad Autónoma Chapingo. México

Odame, H. S., Owuo, J. B. O., Changeh, J. G., \& Otieno, J. O. (2020). The role of technology in inclusive innovation of urban agriculture. Curr Opin Environ Sustain, x(41), 1-6. https://doi. org/10.1016/j.cosust.2019.12.007

Rao, P. S., Navinchandra, S., \& Jayaveera, K. N. (2012). An important spice, Pimenta dioica (Linn .) Merill: A Review. International 
Current Pharmaceutical Journal, 1(8), 221-225. https://doi.org/10.3329/icpj. v1i8.11255

Rema, J., \& Krishnamoordthy, B. (2012). Allspice. Woodhead Publishing Limited, 166-192 https://doi.org/10.1533/9780857095688.166

Reyes-Martínez, A. (2017). Chiapas exportando pimienta gorda. IICA.

Rogers, E. M. (1995). Diffusion of innovations. In Macmillian publishing co. (3rd ed.). The Free Press. https://doi.org/citeulike-article-id:126680

Sol-Sánchez, Á., López-Juárez, S. A., Córdova-Ávalos, V., \& Gallardo-López, F. (2018) Productividad potencial del SAF cacao asociado con árboles forestales. Revista Iberoamericana de Bioeconomía y Cambio Climático, 4(7), 862-877. https://doi org/10.5377/ribcc.v4i7.6327

Ullah, A., Arshad, M., Kächele, H., Khan, A., Mahmood, N., \& Müller, K. (2020). Information asymmetry, input markets, adoption of innovations and agricultural land use in Khyber Pakhtunkhwa, Pakistan. Land Use Policy, 90(xxx), 104261. https://doi.org/10.1016/j. landusepol.2019.104261

UTE-Innovación (Unidad Técnica Especializada en Gestión de la Innovación). (2013). Informe de operación 2012. Proyecto Estratégico Trópico Húmedo. CIESTAAM - UACh, México.

Vargas-Canales, J. M., Palacios-Rangel, M. I., Aguilar-Ávila, J., Camacho-Vera, J. H., OcampoLedesma, J. G., \& Medina-Cuellar, S. E. (2018). Efficiency of small enterprises of protected agriculture in the adoption of innovations in Mexico. Estudios Gerenciales, 34(146), 52-62. https://doi.org/10.18046/j.estger.2018.146.2811

Zainal, M., \& Hamzah, S. R. (2018). Urban Agriculture: The Role of Knowledge among Farmer in Malaysia. International Journal of Academic Research in Business and Social Sciences, 7(14), 77-85. https://doi.org/10.6007/ijarbss/v7-i14/3653

Zhang, L., \& L. Lokeshwar, B. (2012). Medicinal Properties of the Jamaican Pepper Plant Pimenta dioica and Allspice. Current Drug Targets, 13(14), 1900-1906. https://doi org/10.2174/138945012804545641

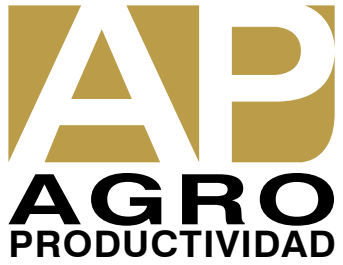

